Ajankohtaiset

\title{
Lönnrotin katse tulevaisuuteen
}

\author{
Lectio praecursoria Turun yliopistossa 18.5.2019
}

Juhana Saarelainen

$\mathrm{E}$ lämme aikaa, jolloin halu erotella kansoja, kansallisuuksia ja kulttuureja näyttää vahvistuvan. Monokulttuurisuuden käsite on tullut yleisesti tunnetuksi. Siellä, täällä, joka puolella vaaditaan paluuta jonnekin tai halutaan jotain takaisin. Katse on suunnattu menneisyyteen yhtenäisen kansallisen kulttuurin nimissä. Elias Lönnrotin (1802-1884) työskentely 1800-luvulla on määritellyt suomalaista kulttuuria mitä suurimmassa määrin. Hänen Kalevalansa tunnustetaan kansalliseksi symboliksi.

Vaadittaessa paluuta menetetyksi miellettyyn yhtenäiseen, niin sanottuun suomalaiseen kulttuurin, on hyvä muistaa, että se rakennettiin suurelta osin 1800-luvun aikana. Silloin ei kuitenkaan katsottu taaksepäin eikä haluttu palauttaa menneisyyden kulttuurimuotoja takaisin silloiseen nykyhetkeen. Lönnrot vitsaili niiden kustannuksella, jotka tällaisesta haaveilivat. Väitöstut-

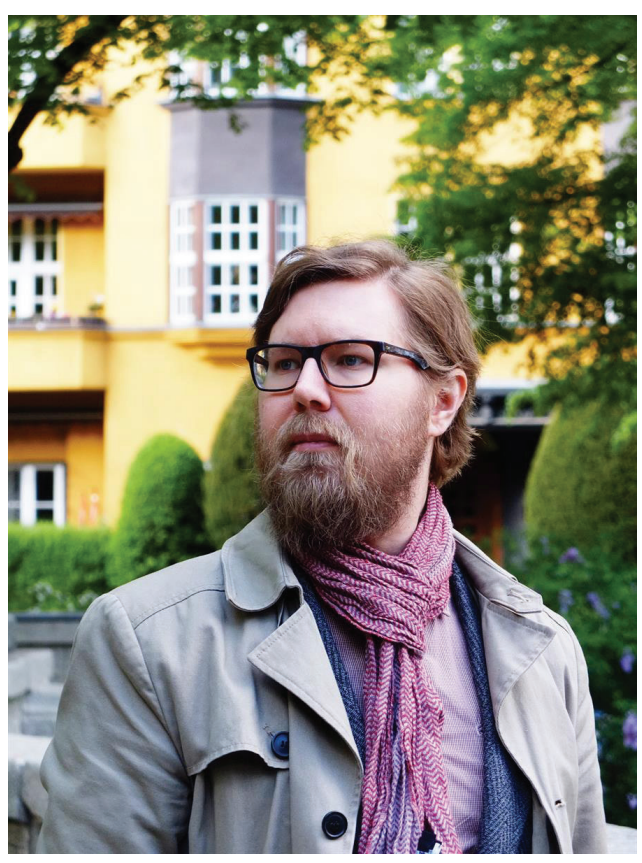

Juhana Saarelainen. Kuva:Turun yliopisto.

kimukseni esittää, että kerätessään esimodernia kansanrunoutta Lönnrot katsoi moderniin tulevaisuuteen. Hän toki oli kiinnostunut muinaisesta suomalaisesta kulttuurista ja halusi tietää siitä niin paljon kuin mahdollista. Hän ei kuitenkaan haaveillut paluusta menneisyyteen, vaan halusi kulttuurin edistyvän. Taaksepäin kääntyminen oli hänelle mahdotonta, jopa naurettavaa, paikallaan pysyminen puolestaan tarkoitti kuolemaa.

\section{Kulttuurin luonnollinen prosessi}

Lönnrot oli omaksunut runsaasti käsityksiä saksalaisen filosofin F. W. J. Schellingin (17751854) ajattelusta. Schellingin luonnonfilosofian ydinajatusta seuraten Lönnrot katsoi, että materiaalinen ja ideaalinen, luonto ja ihminen, ovat ilmausta yhdestä perustasta. Hän ajatteli monistisesti, esittäen että kulttuurin ja luonnon välillä ei ole suurta kuilua, vaan ne kuuluvat samaan kokonaisuuteen. Tämä tulee erinomaisesti esille Lönnrotin päiväkirjassa, jossa hän kirjoitti kielen olevan kuin mikä tahansa elävä olento: se syntyy, kehittää itse itseään ja lopulta kuolee. Näin hän yhdisti inhimillisen kielen, eli kulttuurin, ja luonnon. 
Kulttuurit olivat Lönnrotille prosesseja. Vastaavasti huomautuksissaan Kalevalan uuteen painokseen hän kirjoitti, että elävä sana on henkinen siemen, se kylvetään aikaan ja tuotettuaan jotain uutta ja parempaa se katoaa. Lönnrot tarkoitti suullista kansanrunoutta. Hän uskoi sen aikakauden olevan kohta ohitse. Suomalaisessa suullisessa runoudessa oli kuitenkin se etu, että sen perinne oli vielä elävä. Siinä oli samaa elävää, dynaamista ja sisäistä voimaa kuin luonnossa.

Suullisen runouden lajit olivat Lönnrotin mukaan syntyneet progressiossa. Hän kirjoitti, että ihmiskunnan alusta alkaen on soitettu ja laulettu. Ensin jopa ilman sanoja. Sanattomasta äänteellisestä laulusta runous kasvoi ja monipuolistui, alkaen laulurunosta ja päätyen draamalliseen runouteen. Seuraavana olisi vuorossa kirjallinen runous. Suullisen ja kirjallisen runouden välillä ei siten ollut kuilua vaan jatkumo, siirtyminen suullisesta kirjalliseen oli vain luonnollista.

Schellingin luonnonfilosofiassa luonto asteittain saa uusia voimia yksinkertaisesta painosta monimutkaisiin kemiallisiin prosesseihin, vastaavasti myös kulttuurin kehittyminen saa aikaan uusia kykyjä. Lönnrotin mukaan kirjoitustaito nostaa puheen toiseen potenssiin, ja painokone tekee samoin käsikirjoituksille. Hän kuvaili Kalevalaa niin laajaksi eepokseksi, että kukaan yksilö ei sitä voisi koskaan muistaa. Ihmisyksilön muisti ulkoistettiin painetulle kirjalle Kalevalassa. Lönnrotin mukaan painetun kirjan myötä katoaa muistilta laulamisen arvo ja arvon kadottua katoaa itse laulukin, hän kirjoittaa Uuden Kalevalan esipuheessa. Lönnrot arvosti suunnattomasti runonlaulukulttuuria, mutta hän ei nähnyt sille tulevaisuutta. Voidaan myös kysyä, millä oikeudella hän otti suulliset runot haltuunsa, muokkasi niitä parhaaksi katsomallaan tavalla ja julkaisi ne toimittamassaan muodossa. Lönnrot käytti tiedollista etuoikeutta suhteessa runonlaulajiin.

Lönnrot kuitenkin itse näki, että hänen elinaikansa olisi viimeinen tilaisuus kerätä kansanrunot, ennen kuin ne katoaisivat lopullisesti. Tavoite oli myös emansipatorinen. Lönnrot näki oman äidinkielensä puhujien sekä koko suomen kielen potentiaalin jääneen käyttämättä. Häntä suretti nähdä älykkäitä, mutta oppimattomia suomen kielen puhujia, joille oli tarjolla vain uskonnollista luettavaa, eivätkä he siten voineet kehittää itseään. Dynaamisuus ja elämä olivat Lönnrotille kulttuurin keskeinen määre, ilman kehitystä seuraisi kuolema.

Lönnrot oli todistanut matkoillaan kuinka kielet ja kulttuurit saattoivat kadota. Siksi hän lausuikin ensimmäistä suomenkielistä väitöskirjaa tarkastettaessa, että sivistymätön kansa sivistyneiden kansojen ympäröimänä voi säilyä ainoastaan itsekin sivistymällä, kulttuurisesti kehittymällä. Ihmisyys oli universaalia mahdollisuutta itsensä kehittämiseen ja myös suomalaiset ansaitsivat mahdollisuuden omankieliseen koulutukseen, kirjallisuuteen, tieteeseen, lehdistöön ja hallintoon. Lyhyesti sanottuna moderniin maailmaan.

\section{Toisiinsa kietoutuvat periferiat ja keskukset}

Mahdollisuus, että nämä instituutiot voitaisiin saada aikaan suomen kielellä, ei ollut itsestään selvyys. Aikalaisille tähän tavoitteeseen liittyi epävarmuutta, he eivät voineet nähdä tulevaisuuteen. Mahdollisuus suomenkieliseen sivistykseen Lönnrotin näkemyksen mukaan löytyi kaukaisesta periferiasta. Syvältä sisämaasta, jossa suomenkielinen kansa oli pitänyt muistissaan vanhat, muinaiset runot. Lönnrotin mukaan juuri syrjäisillä, oppimattomilla alueilla kansan runot olivat säilyneet parhaiten. Siellä ihmiset eivät osanneet lukea, ja jos 
olisivatkin osanneet, ei kirjoja olisi ollut kuitenkaan saatavilla. Perifeerisyys tarkoitti, että moderni kirjallinen kulttuuri tai kirjapainon tapaiset tekniset innovaatiot eivät olleet päässeet vaikuttamaan runonlaulukulttuuriin.

Kuten luonto luo itse itseään tiedostamatta, Lönnrotin mukaan myös kansanrunous taidemuotona syntyy kuin itsestään. Hän tiesi yksittäiset runonlaulajat ja heidän erilaiset kykynsä ja taitonsa yksilölliseen ilmaisuun. Kuitenkin kansanrunous oli myös kollektiivista luonnonrunoutta. Sitä tuotettiin tiedostamatta, ilman reflektiota tai aikomusta, luonnon tavoin. Oppimattomalle kansalle runous oli myös tietoa. Se kertoi historiasta, asioiden ja ilmiöiden alkuperästä, sen avulla parannettiin ja tunnettiin yhteisön normit.

Lönnrot näki kuitenkin, että runous ei ollut ainoastaan sisällöllistä tietoa, vaan sen muodossa itsessään oli tiedollinen elementti. Kansanrunoudessa koko luonto, myös eloton, kerrottiin eläväksi. Tähän ei hänen mukaansa enin osa modernista tieteestä tai runoudesta pystynyt. Lönnrotin tulkinta kansanrunoudesta ja sen tavasta kohdata luonto itsessään aktiivisena ja itse itseään luovana on kuin runollinen muunnelma Schellingin luonnonfilosofiasta. Lönnrot yhdistää oman aikansa tuoreen tieteellisen ja filosofisen keskustelun esimoderniin suulliseen runouteen. Runous tuotti tietoa omalla tavallaan. Lääketieteen väitöskirjassaan Lönnrot luonnehti tätä kansanrunouden tietoa tiedon yöpuoleksi. Siellä hän kirjoittaa, että tiedon yöpuoli ilmenee unissa ja aavistuksissa. Se on vastakkaista aistimuksille, ymmärrykselle ja järjelle, jotka ovat vain puolikas inhimillisestä tiedon kyvystä. Tiedon yöpuoli tulee esille juuri kansanrunoudessa. Kansanrunous, Lönnrotin mukaan, tarkasteli luontoa kauttaaltaan toimivana, dynaamisena ja itse itseään uudistavana. Ei vain elollista luontoa vaan myös elotonta luontoa määritti sen sisäinen voima. Kalevalan alussa kerrottua kosmogoniaa Lönnrot tulkitsi siten, että alkumeressä raskaaksi tuleva veden emo, vaikka on personifikaatio, ei ole persoonallinen veden jumaluus. Sanat emo ja emä ovat tarkoittaneet muinaisille suomalaisille sitä, mistä kullakin aineella on oma ylläpitonsa, lujuutensa ja vahvuutensa: veden emo on veden omaperäinen voima.

Myös eräät ajan uusimmat luonnontieteelliset teoriat olivat havainneet luonnon itsenäisen toimijuuden. Muinainen esimoderni runous Lönnrotin määritelmän mukaan tuotti omalla tavallaan saman tiedon kuin ajankohtaisin mahdollinen luonnontiede ja filosofia. Näin sivistys ja sivistymättömyys, oppineisuus ja oppimattomuus ja keskukset ja periferiat sekoittuvat ja kietoutuvat toisiinsa hänen ajattelussaan ja toiminnassaan.

\section{Kalevala, omaa lajiaan}

Lönnrot tunsi aikakautensa filosofia keskusteluja, mutta hän ei ollut vain niiden passiivinen vastaanottaja. Hän tulkitsi ja sovelsi niitä ajattelussaan ja työskentelyssään. Kansanrunous oli hänelle kulttuuria, mutta myös kuin luonnonvoima. Se oli elävää kulttuuria, jota saatettiin kehittää eteenpäin kohti kirjallisuutta. Juuri tällainen yritelmä oli Kalevala. Siinä Lönnrot sekoitti suullista ja kirjallista kulttuuria, esimodernia ja modernia. Hän suuntautui yhtäaikaisesti kohti aikakauden oppineita keskuksia ja oppimattomia periferioita, mutta teki niistä liikkuvia ja toisiinsa kietoutuvia. Hän siirsi suullista runonlaulukulttuuria kirjalliseen ja painettuun muotoon. Se mahdollisti kansanrunoudelle uusia kykyjä.

Kalevalan avulla suomalainen kansanrunous siirrettiin suullisesta kulttuurista ja oppimattomasta periferiasta Berliiniin, Pariisiin ja Lontooseen. Eeposta lukivat aikansa kuuluisat 
tiedemiehet, kirjailijat ja poliitikot. Jacob Grimm, Victor Hugo ja Benjamin Disraeli olivat aikalaistodistusten mukaan haltioituneita Kalevalasta. Eepoksesta tuli maailmankirjallisuutta. Kalevala on monta eri asiaa. Se on kaunokirjallinen runoteos, se on myös kokoelma kansanrunoutta, Kalevala on filologinen työ, joka on muokannut suomen kieltä. Se on suullista kansanrunoutta, jota Lönnrot on muokannut kirjalliseen muotoon. Kalevala on yksi teos, Suomen kansalliseepos ja kuitenkin myös monta teosta, joukko käsikirjoituksia ja kolme toisistaan poikkeavaa painettua laitosta.

Tämä eepos pakenee määrittelyjä. Se on kirjallinen, mutta se perustuu suulliseen runouteen. Se on Lönnrotin aikaansaannos, mutta se ei olisi ollut hänelle mahdollinen ilman suurta joukkoa kansanrunon laulajia - tai muita kansanrunon kerääjiä, jotka toimittivat Lönnrotille keräämäänsä aineistoa. Siten Kalevala on myös kollektiivinen teos. Se on runoutta, mutta sillä on myös yhteiskunnallisia ja tieteellisiä, filologisia ja etnografisia pyrkimyksiä. Lönnrotin toimitustapa ei ollut satunnainen, vaan hän pyrki yhdistelemään runoja ja kansanrunouden eri lajeja tuottaakseen mahdollisimman monipuolisen kuvan suomalaista kulttuurista.

Kalevala ei olisi ollut mahdollinen ilman suullista kansanrunoutta, mutta ei sitä olisi myöskään koskaan koostettu ilman laajaa ylikansallista aatteellista, tieteellistä ja filosofista asiayhteyttä. Lönnrot liittyi tähän ylirajaiseen kontekstiin sujuvasti, vaikka suuntasi matkansa oppimattoman kansan keskuuteen, eikä Euroopan oppineisiin keskuksiin. Kalevalassa ja Lönnrotin työskentelyssä runous, tieto ja kansa kietoutuvat toisiinsa. Kalevalan säkeet on kuultu kansan suusta, oppimattoman ja turmeltumattoman, kuten Lönnrot ajatteli. Toisaalta Kalevala loi kansaa, se oli Lönnrotin oma ajatus: hän kertoi haluavansa kerätä ja julkaista kansanrunoutta, jotta kaikki suomalaiset voisivat päästä osalliseksi sen yksinkertaisesta voimantäyteistä kielestä ja viisaudesta. Hän halusi muokata kansanrunouden kieltä kohti yhtä yhtenäistä suomea.

Suullisen runouden muuttaminen kirjallisuudeksi sekoitti ja yhdisteli erilaisia kulttuurisia kokonaisuuksia. Kalevala on kulttuurituotteena hybridinen teos. Kalevala tosiaan pakenee kaikkia määrittelyjä, se on sui generis, omaa lajiaan.

\section{Hybridinen, uudistuva kulttuuri}

Väitöstutkimukseni tarkastelee runouden, tiedon ja kansan yhteenkietoutumista osana aikakauden ylirajaisia filosofisia keskusteluja. Se osoittaa näiden käsitteiden määritelleen toisiaan 1800-luvun alkupuolen Suomessa. Jokainen niistää liittyy toiseensa. Käsitteiden rajat ovat siten häilyviä. Ne ovat kulttuurisesti ja historiallisesti muotoutuneita, eikä niiden merkitystä menneisyydessä voida ottaa annettuna, vaikka ne ovatkin kovin tuttuja.

Toivon, että väitöstutkimukseni osoittaa, että keskustelu suomalaisuudesta ja suomalaisesta kulttuurista syntyi ylikansallisesti. Historiallista suomalaisuutta ei voi ymmärtää ilman ylirajaisia konteksteja. Suomalaista kulttuuria määritellyt Lönnrotin ajattelu, toiminta ja hänen Kalevalansa jäävät monin paikoin ymmärtämättä, jos niitä ei lueta ylirajaisessa kontekstissa. Kalevalaa tai suomalaisuutta ei olisi voinut tuottaa yksinään kansallisesti, yhtä paljon niitä mahdollisti ylikansallisuus ja transkulttuurisuus.

Tutkimuksessani tulee ilmi, että kulttuuri ei ole yhtenäinen. Kulttuurit ovat sekoittuneita ja ne ovat jatkuvassa liikkeessä. Olen tarkastellut aikaa, jolloin suomalaisuus ja moderni 
suomalainen kulttuuri syntyivät. Ne eivät kuitenkaan syntyneet yhtenäisestä alkuperästä, vaan sekoittaen ja hämmentäen. Lönnrotin ajattelu ja toiminta ja niiden tuottama Kalevala pitää ymmärtää kulttuurisesti hybridisinä. Lönnrotin mukaan kulttuurin pitikin olla jatkuvassa muutoksen tilassa. Suullisen ja kirjallisen tuli sekoittua ja muodostaa jotain uutta ja ennen näkemätöntä.

Voimme kuvitella, että Lönnrot ei toiminnallaan halunnut luoda paikallaan pysyvää suomalaisuutta. Hän olisi toivonut, että myös tulevaisuudessa suomalainen kulttuuri voisi jatkaa kehittymistään, että se ei jäisi ajastaan jälkeen, vaan muuttuisi sen mukana. Hän olisi halunnut sen tuottavan yhä uudelleen jotain uutta, jotain mitä koskaan aiemmin ei ollut ollut olemassa.

Saarelainen, Juhana. 2019. Runous, tieto ja kansa. Elias Lönnrotin ajattelu ja toiminta aikalaisfilosofian kontekstissa. Turun yliopisto: Turku.

[http://urn.fi/URN:ISBN:978-951-29-7650-8]

\section{Aineistot}

\section{Käytetyt Lönnrotin teokset}

"Alkuluomisesta."Teoksessa VT2, 557-560.

"Anmärkningar till den nya Kalevala upplagan."Teoksessa VT5, 402-408.

"Kalevala." [Alkulause] Teoksessa VT5, 409-417.

"Kalevalan sisällyksestä." [kirje Léouzon Le Ducille] Teoksessa VT5, 471-477.

"Kanteletar." [Alkulause] Teoksessa VT5, 319-359.

"Något om dialecternas företräden i Finskan."Teoksessa VT3, 116-117.

"Om finnarnes magiska medicin."Teoksessa ELSS1, 1-36.

"Puhe Rietrikki Polenin väitöstilaisuudessa."Teoksessa VT3, 483-485.

"Reseanteckningar af Lönnrot."Teoksessa ELSS2, 375-398.

Sine nomine. [kirje C. A. Gottlundille] Teoksessa VT1, 17-18.

Sine nomine. [kirje Suomalaisen Kirjallisuuden Seuralle] Teoksessa VT1, 123-125.

\section{Lyhenteet}

ELSS1 = Lönnrot, Elias. 1908. Elias Lönnrots Svenska skrifter I. Uppsatser och öfversättningar, toim. Jenny af Forselles. Helsinki: Svenska Litteratur Sällskapet i Finland.

ELLS2 = Lönnrot, Elias. 1911. Elias Lönnrots Svenska skrifter II. Bref, anteckningar och reseskildringar, toim. Jenny af Forselles. Helsinki: Svenska Litteratur Sällskapet i Finland.

VT1 = Lönnrot, Elias. 1990. Valitut teokset 1. Kirjeet, toim. Raija Majamaa. Helsinki:Suomalaisen Kirjallisuuden Seura. 
VT2 = Lönnrot, Elias. 1990. Valitut teokset 2. Mehiläinen, toim. Raija Majamaa. Helsinki: Suomalaisen Kirjallisuuden Seura.

VT3 = Lönnrot, Elias. 1991. Valitut teokset 3. Kirjoitelmia ja lausumia, toim. Raija Majamaa. Helsinki: Suomalaisen Kirjallisuuden Seura.

VT5 = Lönnrot, Elias. 1993. Valitut teokset 5. Muinaisrunoutta, toim. Raija Majamaa. Helsinki: Suomalaisen Kirjallisuuden Seura. 